\title{
Roughhead Grenadier (Macrourus berglax) in the Waters off East Greenland: Distribution and Biology
}

\author{
Inge Fossen \\ Møre Research, Section of Fisheries, P. O. Box 5075, N-6021 Aalesund, Norway \\ Ole A. Jørgensen \\ Danish Institute for Fisheries Research, Charlottenlund Slot, DK 2920, Charlottenlund, Denmark \\ Agnes C. Gundersen \\ Møre Research, Section of Fisheries, P. O. Box 5075, N-6021 Aalesund, Norway
}

\begin{abstract}
The study focuses on distribution, catch rates and biological parameters of roughhead grenadier (Macrourus berglax) at East Greenland based on data from trawl surveys, longline surveys and commercial catches from the period 1994-2000. Roughhead grenadier was recorded at most fished stations at depths between 200 and $1600 \mathrm{~m}$. Catch rates and length frequencies varied both with gear, areas, depth and year. The observed patterns are at least partly caused by a separation of sex and length groups by depth strata. The catch rates were highest at depths between 1000 and $1500 \mathrm{~m}$ in the longline surveys and between 800 and $1200 \mathrm{~m}$ in the trawl surveys. In both types of surveys the length distributions were dominated by a modal peak around $20 \mathrm{~cm}$ (PAF). Sex ratio changed with depth and length of $50 \%$ maturity $\left(L_{50}\right)$ was estimated to be at 16 and $29.5 \mathrm{~cm}$ for males and females, respectively. Estimate of potential fecundity from 25 specimens varied between 17-56 000 eggs per specimen.
\end{abstract}

Key words: biology, catch rates, distribution, East Greenland, Macrourus berglax, roughhead grenadier

\section{Introduction}

Roughhead grenadier (Macrourus berglax) occurs in relatively cold water $\left(-0.5\right.$ to $5.4^{\circ} \mathrm{C}$; Atkinson and Power, MS 1987) along the continental shelf throughout the North Atlantic Ocean, at depths between 200 and $2000 \mathrm{~m}$ (Savvatimsky, 1969; Parsons, 1976; Murua, MS 2000). Roughhead grenadier is caught commercially mainly in NAFO Div. $3 \mathrm{LMN}$ in the Regulatory Area as by-catch in the fishery for Greenland halibut (Reinhardtius hippoglossoides) (Anon., 2002). Based on its frequent occurrence in catches over a much wider area, it might represent a potential for further commercial utilization (Jørgensen, 1995; 1996; MS 2001; Magnússon and Magnússon, 1995; Olsen, 1995; Parsons, 1976; Savvatimsky, 1985.)

In Greenland waters roughhead grenadier is a common by-catch both in the longline fishery for Greenland halibut or Atlantic halibut, and in the trawl fishery for Greenland halibut (Jørgensen, 1995, MS 2001). Indications of catch rates and relative abun- dance are given from scientific and commercial vessels from several areas in the North Atlantic and abundance seems to differ between areas and depths (Eliassen, MS 1983; Jørgensen, 1995; MS 2001; Magnússon and Magnússon, 1995; Olsen, 1995; Parsons, 1976).

Although knowledge about biological characteristics of roughhead grenadier is limited, a number of studies have described different aspects of its biology (Jørgensen, 1995, 1996; Katsarou and Nævdal, 2001; Murua and Motos, 2000; Swan and Gordon, 2001; Savvatimsky, 1985). Females seem to mature at about 14 years of age (Eliassen, MS 1983; Murua and Motos, 2000 ) and the rate of growth is relatively slow (Jørgensen, 1996; Murua and Motos, 2000). Spawning occurs throughout the year with a peak during winter/spring (Geistdoeffer, 1979; Magnússon and Magnússon, 1995; Savvatimsky, 1984; 1985; Eliassen and Falk-Petersen, 1985). The potential fecundity seems to vary between approximately 14000 and 80000 eggs per individual (Murua and Motos, 2000). 
This study summarizes information about distribution, catch rates and some biological parameters for roughhead grenadier based on data from scientific bottom trawl and longline surveys and sampling of commercial catches along the eastern coast of Greenland.

\section{Materials and Methods}

Data were collected during longline and bottom trawl surveys conducted since 1994 along the east coast of Greenland. The bottom trawl data were collected during three surveys in 1998, 1999 and 2000. The surveys were conducted as stratified random bottom trawl surveys and covered the area from $61^{\circ} 30^{\prime} \mathrm{N}$ to $66^{\circ} 00^{\prime} \mathrm{N}$ at depths between 400 and $1500 \mathrm{~m}$ during June and July each year. The mesh size was 140 $\mathrm{mm}$ with a $30 \mathrm{~mm}$ mesh liner in the cod end. Further information about surveys and gear is presented elsewhere (Jørgensen, MS 2001, MS 1998). Longline data were sampled during 4 years (1994, 1996, 1997 and 2000 ) in the area from $60^{\circ}$ to $64^{\circ} \mathrm{N}$ at depths between 300 and $1600 \mathrm{~m}$. All surveys used bottom sets with Mustad No 12 hooks baited with mackerel or squid. All surveys were conducted between June and August each year. Further, sampling was carried out during July/August 1998 and August 2000 on board commercial trawlers targeting Greenland halibut in subarea Q2 at depths between 600-800 m (Fig. 1). The mesh

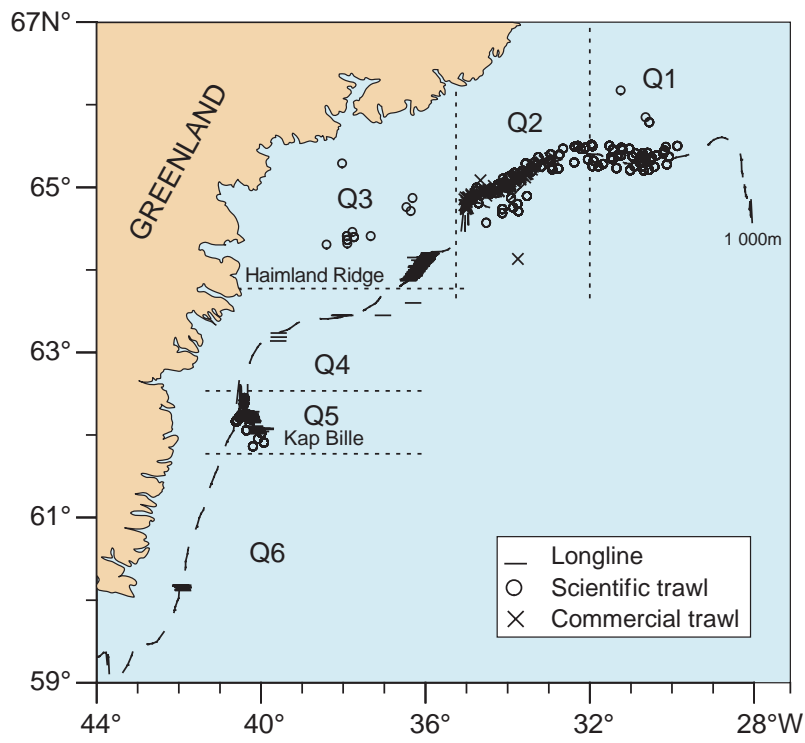

Fig. 1. Survey area map showing subareas (Q1-Q6) and location of stations with recorded catches of roughhead grenadier by gear. size in the cod end was $140 \mathrm{~mm}$. Length distribution and catch rates were given for five subareas Q1-Q6 (Fig. 1) and seven depth strata (200-400, 401600, 601-800, 801-1 000, 1 001-1 200, 1 201-1 400 and 1 401-1 $600 \mathrm{~m}$ ). Effort within the different areas and strata varied both between surveys and gear.

For all surveys, length distribution and catch rates were estimated by station. Sex, maturity and individual weight were recorded at a number of stations. In the trawl surveys catch rates were standardized to $\mathrm{kg}$ per $\mathrm{km}^{2}$ swept. In the longline surveys catch rates were estimated as kg per 1000 hooks.

Length was measured as pre-anal fin length $(P A F)$ in $0.5 \mathrm{~cm}$ increments during scientific trawl surveys and pre-anal length in $1.0 \mathrm{~cm}$ increments from longline and commercial catches. For comparison all length measures from longline and commercial catches was transformed to PAF following the equation: $P A F=1.0634 \times \mathrm{AL}-0.1435, r^{2}=0.9976, n=$ 316 , sexes combined. Length frequencies were compared both graphically and by the use of the two-sided Kolmogorov-Smirnov statistics (Zar, 1984).

Subjective determination of stage of maturity was recorded according to a general 5 -stage scale (Table 1). The length where $50 \%$ of the individuals reach maturity $\left(L_{50}\right)$ was estimated for each sex by fitting a logistic growth function to the proportion of mature individuals within different length-groups (I, II). Each observation was weighted to the number of observations within each length-group during the fitting process. The model was fitted by use of the "least squares" method.

Logistic growth curve:

$$
Y=100 /\left(1+e^{a+b X}\right)
$$

$Y=$ portion mature individuals (\%).

$X=$ length group.

$a$ and $b=$ estimated parameters for each sex.

$L_{50}$ given by: $\quad L_{50}=-a / b$

Potential fecundity for individual roughhead grenadier was estimated based on counts of eggs in subsamples of the whole gonad and total gonad weight. Samples were collected during the longline survey in 2000 and the fecundity was estimated according to Gundersen et al. $(1999,2001)$. 


\section{Results}

\section{Distribution}

\section{Catch rates}

Trawl. In the scientific trawl surveys, the catch rates were generally largest in subarea Q1, within the same range in Q2 and Q5 and very low in Q3 (Q4 has not been covered due to rough bottom) (Jørgensen, MS 2001). The largest average catch rates within a depth stratum, up to 0.8 tons per $\mathrm{km}^{2}$, was found in Q1 at depths between 800 and $1000 \mathrm{~m}$ and in all subareas the highest catch rates generally were found at depths between 800 and $1200 \mathrm{~m}$ (Table 2; Fig. 2; Jørgensen, MS 2001).
All the scientific trawl surveys covered the same geographic area (Fig. 1). Significant differences in catch rates between years were only found for the $1400-1600 \mathrm{~m}$ depth stratum in subarea Q5 $\left(F_{2,7}=\right.$ 9.929, $p=0.028)$, where average catch rate during 2000 was significantly higher than during 1998 and 1999 (pairwise mean differences Bonferroni statistics, $p<0.001)$. In general, no differences in catch rates were observed between years for any of the subareas ( $F$ stat., $p>0.15$ ) and data were pooled to increase sample size.

Significant differences in catch rates by depths were found only in subarea Q1 $\left(F_{5,42}=4.279, p<\right.$ $0.004)$. Here the catch rate in the $800-1000 \mathrm{~m}$ stra-

TABLE 1. Maturity scale used for roughhead grenadier (after Fotland et al., 1997).

\begin{tabular}{ll}
\hline \hline Stage & \multicolumn{1}{c}{ Description } \\
\hline 1 & Juvenile/immature: Gonads are small, eggs or milt not visible to naked eye. \\
2 & Maturing: Gonads are developing (maturing). Eggs and milt visible to naked eye but not running. \\
3 & Running: Ovaries and testes are in running condition. \\
4 & Spent: Shortly after spawning. Gonads are usually loose and reddish. Eggs or milt not visible to naked eye \\
5 & Uncertain: Not possible to distinguish between immature and mature. \\
\hline
\end{tabular}

TABLE 2. Average catch ratio by gear, year and depth interval for different subareas Q1-6. Sci. T = Scientific Trawl surveys. LL $=$ Longline surveys. Numbers given in kg per naut. mile ${ }^{2}$ and $\mathrm{kg}$ per 1000 hooks for trawl and longline respectively (number of stations).

\begin{tabular}{|c|c|c|c|c|c|c|c|c|}
\hline \multirow[b]{2}{*}{ Gear } & \multirow[b]{2}{*}{ Subarea } & \multirow[b]{2}{*}{ Year $^{1}$} & \multicolumn{6}{|c|}{ Catch Ratio at Depth $(100 \mathrm{~m})$} \\
\hline & & & $401-600$ & $601-800$ & $801-1000$ & $1001-1200$ & $1201-1400$ & $1401-1600$ \\
\hline Sci.T & 1 & 1998 & $197.6(15)$ & $315(50)$ & $720.6(86)$ & $387.1(36)$ & $522(22)$ & $428.7(36)$ \\
\hline Sci.T & 1 & 1999 & $349.9(39)$ & $619.8(73)$ & $940.5(84)$ & $654(49)$ & $356(23)$ & $136.8(14)$ \\
\hline Sci.T & 1 & 2000 & $31.6(7)$ & $497.6(61)$ & $772.7(76)$ & $424.8(30)$ & $277.8(24)$ & $998.3(36)$ \\
\hline Sci.T & 2 & 1998 & $32.9(9)$ & $233.2(62)$ & $520(66)$ & $387.9(29)$ & $232.2(24)$ & $38.2(2)$ \\
\hline Sci.T & 2 & 1999 & $87.6(22)$ & $194.5(43)$ & $340.7(79)$ & $362.2(38)$ & $310.3(21)$ & $402(23)$ \\
\hline Sci.T & 2 & 2000 & $227(25)$ & $162.2(36)$ & $268.7(42)$ & $167.5(14)$ & $171.9(17)$ & $288.8(18)$ \\
\hline Sci.T & 3 & 1998 & $7.6(1)$ & $10.8(1)$ & $3.8(5)$ & & & \\
\hline Sci.T & 3 & 1999 & & $2.2(1)$ & & & & \\
\hline Sci.T & 3 & 2000 & $2.1(2)$ & $3.3(2)$ & $7.1(4)$ & & & \\
\hline Sci.T & 5 & 1998 & & & & $176(34)$ & $157.4(22)$ & $167.2(30)$ \\
\hline Sci.T & 5 & 1999 & $15.6(2)$ & 90.7 (23) & $137.8(27)$ & $153.5(28)$ & $62.7(12)$ & $160.9(23)$ \\
\hline Sci.T & 5 & 2000 & & $139.5(28)$ & $199.8(35)$ & $178.2(29)$ & $77.1(13)$ & $353.8(36)$ \\
\hline LL & 3 & 2000 & $144(5)$ & & $126.9(2)$ & & & \\
\hline LL & 4 & 1996 & & & & & $232.3(1)$ & $147.1(2)$ \\
\hline LL & 5 & 1996 & & & & & $102.1(8)$ & \\
\hline LL & 5 & 1997 & & & & $12.8(6)$ & $27.4(7)$ & $144.1(3)$ \\
\hline LL & 5 & 2000 & & & & & $78.8(31)$ & $190.5(1)$ \\
\hline LL & 6 & 1996 & & & $174.8(1)$ & $131.9(2)$ & $209.6(5)$ & $162.5(4)$ \\
\hline
\end{tabular}

\footnotetext{
${ }^{1}$ Data from the 1994 longline survey not available.
} 

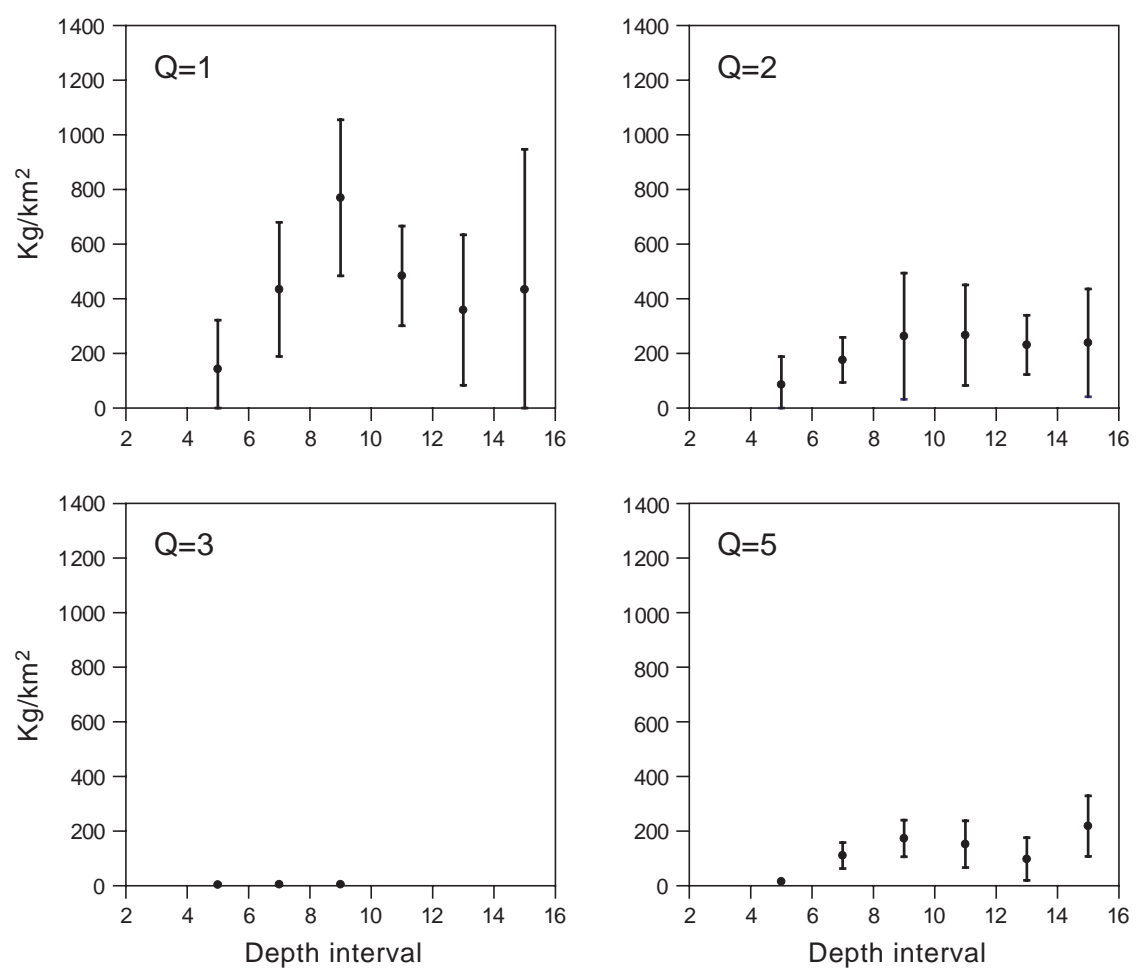

Fig. 2. Catch rates $\left(\mathrm{kg}\right.$ per $\left.\mathrm{km}^{2}\right)$ of roughhead grenadier, all years combined, in scientific trawl surveys by depth stratum and subarea $( \pm 1 \mathrm{SD})$.

tum was significantly higher than in depth stratum 400-600 m. (pairwise mean differences Bonferroni statistics, $p=0.001$, Fig. 2; Table 2).

Differences in catch rates were found between subareas within depth stratum 600-800, 800-1 000 and $1000-1200 \mathrm{~m}$ (pairwise mean differences Bonferroni statistics, $p<0.004)$. In these strata, catch rates in subarea Q1 were significantly higher compared to the same strata in subarea Q3 and/or Q5 (Fig. 2).

Longline. Average catch rates for longline varied between 30 and $230 \mathrm{~kg}$ per 1000 hooks within most areas and depth strata (Table 2). Highest average catch rates were recorded in subarea Q6 while catch rates in both subarea Q3 and Q4 varied around $150 \mathrm{~kg}$ (Fig. 3). In subarea Q5, where most of the commercial longline fishery takes place, average catch rates increased from 13 to $150 \mathrm{~kg}$ with depths between 1000 and $1600 \mathrm{~m}$ (Fig. 3; Table 2).

In general there was no overlap in the areas covered by the different longline surveys. The only exception was depth stratum 1200-1 400 and $1400-$ $1600 \mathrm{~m}$ in subarea Q5, which were covered during 1996, 1997 and 2000. A significant difference in catch rates between years was found in the 1200 to 1400 $\mathrm{m}$ stratum $\left(F_{2,46}=13.512, p<0.001\right)$. Here catch rates in 1997 were significantly lower than in 1996 and 2000 (pairwise mean differences Bonferroni statistics, $p<0.001$; Table 2). Despite this, data from different years were pooled in order to enable a more detailed analysis of distribution by subarea and depth strata. Significant differences in catch rates by depth stratum $\left(F_{2,56}=21.476, p<0.001\right)$ were only found in subarea Q5, where catch rates increased by depth (Fig. 3; Table 2). Within stratum 1000-1 200 and $1200-1400 \mathrm{~m}$, statistically significant differences in catch rates were found between subareas $\left(F_{1,8}=\right.$ $21.263, p=0.004$ and $F_{2,52}=35.444, p<0.001$, respectively). In both strata catch rates in subarea Q5 were significantly lower than catch rates in subareas Q4 and Q6 (Fig. 3).

\section{Length Composition}

Trawl. When length distributions within a subarea and depth stratum, from the scientific trawl surveys, was compared by years only one out of 48 comparisons showed significant differences (Kolmogorov-Smirnov Two Sample Test (K-S) $p<0.05$; Fig. 4). Data from the scientific trawl surveys were hence pooled for further analysis. 

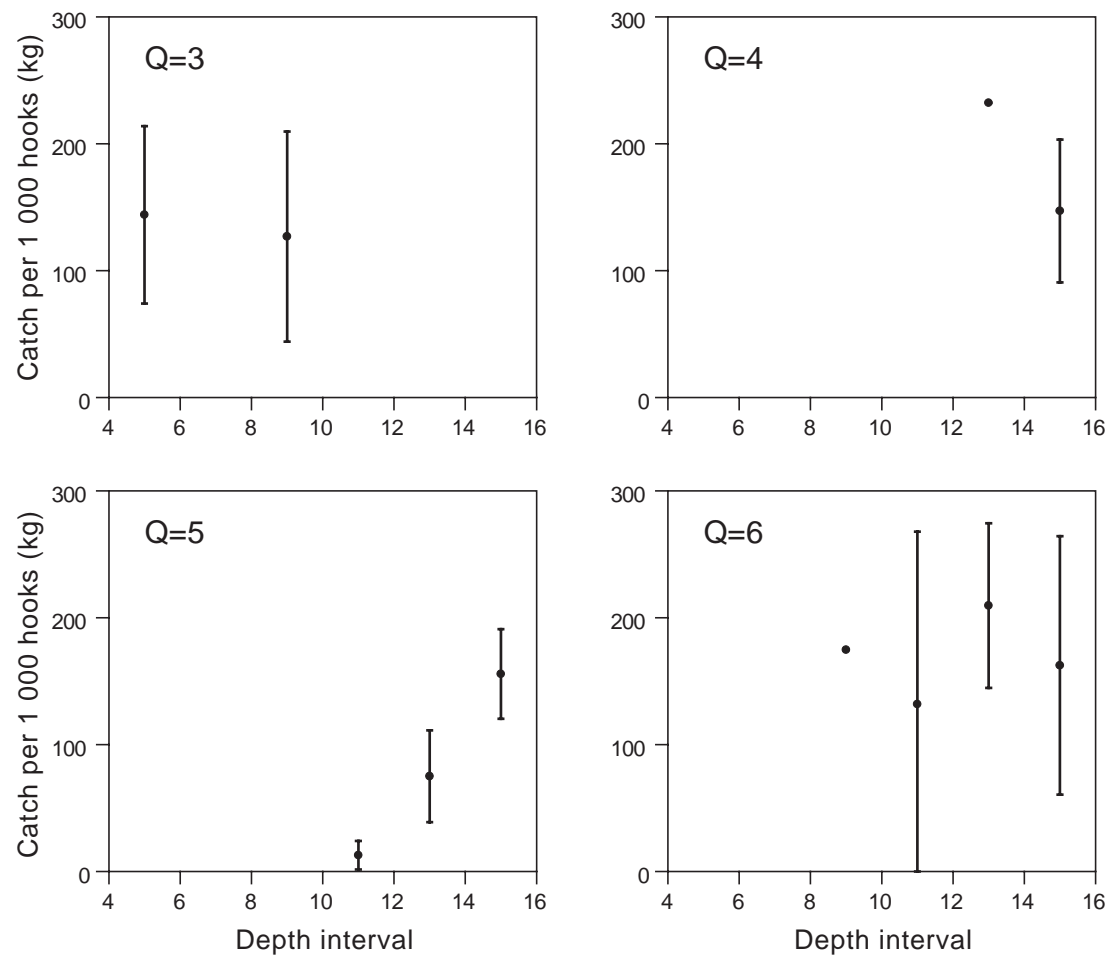

Fig. 3. Catch rates (kg per 1000 hook) of roughhead grenadier, all years combined, in longline surveys by depth stratum and subarea ( $\pm 1 \mathrm{SD})$.

Length frequencies from the scientific trawl surveys were pairwise tested by subarea. Significant differences were found between all areas $(\mathrm{K}-\mathrm{S}$, $p<0.001)$. The main difference resulted from an increasing proportion of larger fish, from subarea Q5 to Q2 and further from Q2 to Q1 (Q3 was not included in the analysis due to few observations and Q4 was not surveyed due to rough bottom) (Fig. 4). Similarly, when length distributions were tested by depth stratum, differences were found between the 800$1000 \mathrm{~m}$ stratum and the 400-600,600-800, $1000-$ 1200 and $1200-1400 \mathrm{~m}$ strata $(\mathrm{K}-\mathrm{S}, p=0.020$, $0.004,<0.001$ and 0.002 , respectively) (Fig. 4; Fig 5 A). A higher proportion of medium sized fish (25$31 \mathrm{~cm}$ ) in the 800-1 $000 \mathrm{~m}$ stratum seems, at least to some extent, to be causing the observed differences.

When length distributions at a certain depth stratum were compared by subareas, statistically significant differences were found in all except one (400$600 \mathrm{~m}$ ) depth strata. In five strata this was caused by a higher proportion of larger fish in subarea Q1 and Q2 compared to Q5 (K-S, $p<0.01$ ) (Fig. 4).

Longline. For longline the only stratum with consecutive sampling of length data was depth stratum 1 200-1 $400 \mathrm{~m}$ in subarea Q5, which was sampled in 1996, 1997 and 2000. Here the length distribution from 2000 differed significantly from distributions obtained during 1996 and 1997 (K-S, $p<0.001$; Fig. 5B). This was due to an increasing proportion of larger fish in 2000 . However all data from the longline survey were pooled to test for possible differences in length distribution between subareas and depth strata.

The length distributions by subarea were tested by a K-S test. Statistical significant differences in the length distributions were found between all areas $(\mathrm{K}-$ $\mathrm{S}, p<0.001)$. The differences were due to a larger proportion of small fish in subarea Q5 and Q6 while larger fish dominated in subarea Q4 (Fig. 6). When length distributions were tested by depth, significant differences were found between most strata (Table 3 ), where the highest proportion of large and small fish being found in the 800-1 $000 \mathrm{~m}$ and 400-800 $\mathrm{m}$ strata, respectively (Fig. 6). When length distributions in each of the seven depth strata were compared between subareas, statistically significant differences were found within all depth strata. In five strata, this was caused by a higher proportion of small fish in subarea Q5 compared to Q4 or Q6 $(\mathrm{K}-\mathrm{S}, p<0.05)$. In depth 

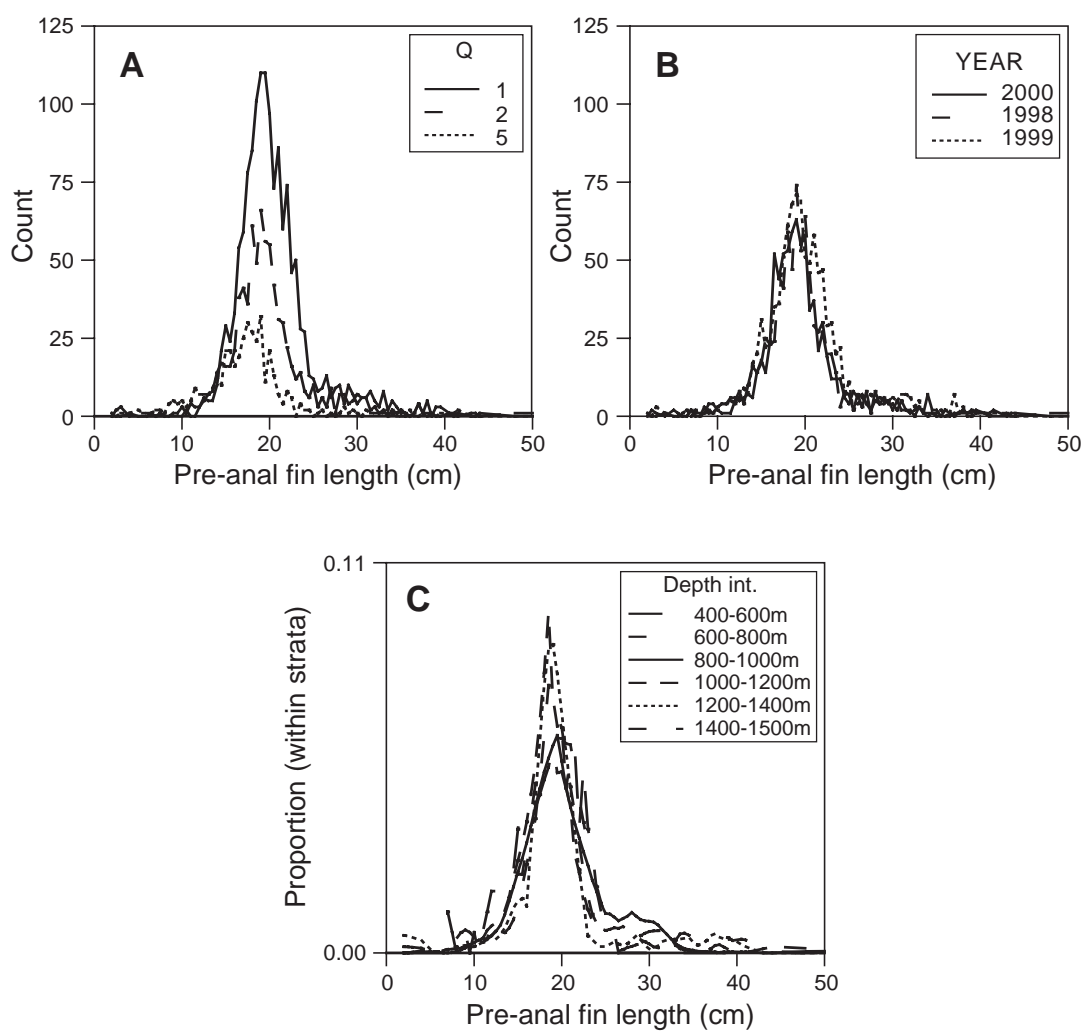

Fig. 4. Length distribution (PAF) of roughhead grenadier, from scientific trawl surveys combined. (A) Length distribution from three subareas, (B) Length distribution from three years, and (C) Length distribution within different depth strata (proportion within strata), smoothing = lowess (Clevland, 1979).

stratum 800-1 $000 \mathrm{~m}$, the difference was caused by a higher frequency of large fish in subarea Q5 compared to Q6.

\section{Commercial trawl}

The length distributions from the commercial trawlers were skewed to the right with a mode at $20 \mathrm{~cm}$ $(P A F)$ (Fig. 5A). However, a significant difference was found between the two surveys $(\mathrm{K}-\mathrm{S}, p<0.001)$, mainly due to a larger proportion of smaller specimens $(<21 \mathrm{~cm})$ in 2000. (Fig. $5 \mathrm{~A})$,

\section{Area covered}

Commercial trawling normally took place within small geographic areas due to a combination of restricted distribution of commercial concentrations of Greenland halibut and difficult trawling conditions, while the scientific trawl surveys covered a much wider depth range. Figure 5A shows the length dis- tribution by depth stratum in the scientific and commercial trawls. In the commercial trawl catches a clear mode around $20 \mathrm{~cm}$ was seen both in 1998 and 2000 while the distribution "tail" representing larger fish seen in 1998 disappeared in 2000. The mode around $20 \mathrm{~cm}$ was also seen in the scientific survey catches but otherwise these length distributions were hard to interpret due to few observations.

The best coverage of both trawl and longlines was in area Q5. Here the longline sets were mainly concentrated at depths where the fishery for Greenland halibut normally took place although sets were also made both shallower and deeper (Fig. 5B). Fish between 15 and $24 \mathrm{~cm} P A F$ dominated the catches during all years, areas, gears and strata. In general maximum fish length increased by depth, but it should be noticed that length distribution differed both between gears, years and depth strata. 


\section{Biological parameters}

\section{Length}

A Kolmogorov-Smirnov Two Sample Test, applied to data from both the combined scientific trawl surveys and the longline survey in 2000 showed a significant difference $(\mathrm{K}-\mathrm{S}, p<0.0001)$ in the length distribution between males and females within both data set (Fig. 7). Males were recorded between 6 and $32 \mathrm{~cm}$ and 13 and $26 \mathrm{~cm}(P A F)$ in the trawl and longline survey, respectively, while females ranged from 5 to $50 \mathrm{~cm}$ and 12 to $46 \mathrm{~cm}$, respectively (Fig. 7).

\section{Sex composition by depth}

Males were much more dominant in the overall trawl catches compared to the longline catches (Fig.7). In the scientific trawl data males significantly dominated the catches in all depth strata (Table 4; Fig. 8). The male dominance was smallest in the 800-1000 m depth stratum (66\%). In the longline material males and females occurred with equal frequencies in the depth strata from 400 to $800 \mathrm{~m}$. Females dominated catches in the 800-1 $000 \mathrm{~m}$ depth stratum while the male dominance increased with depth from 1200 to 1600 m. (Table 4, Fig. 8).

\section{Maturation}

During several of the surveys, subjective determinations of stage of maturity were carried out. Although there seems to be good agreement between years regarding length at sexual maturation, only data collected during the longline survey in subarea Q3 and Q5 during August 2000 are presented to illustrate length at maturity. Apart from being geographically separated, the samples were also taken from different depth strata within the two subareas, 800-1 000 $\mathrm{m}$ in Q3 and 1 200-1 400 in Q5. Of the 301 examined females, 108 were mature and further 3 were spawning. Of the 368 examined males, 339 were mature. The proportion of mature females was higher in Q5 compared to Q3 (47.5\% and 24.5\%) while the opposite was observed among males $(89.75 \%$ and $96.8 \%)$.

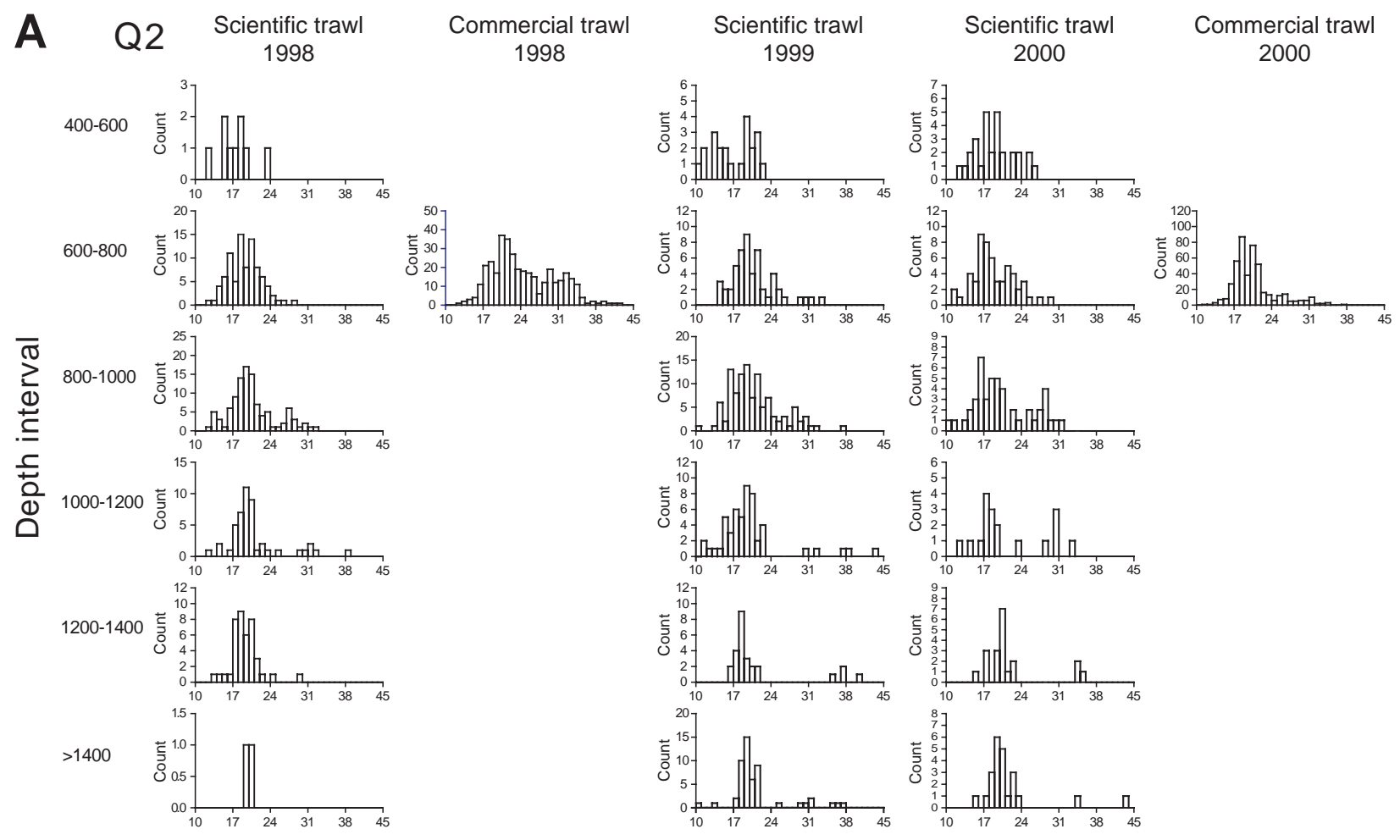

Pre-anal fin length $(\mathrm{cm})$

Fig. 5A. Pre-anal for length $(P A F)$ distribution of roughhead grenadier. Example from subarea Q2 - data from scientific trawl surveys and commercial trawl catches. 


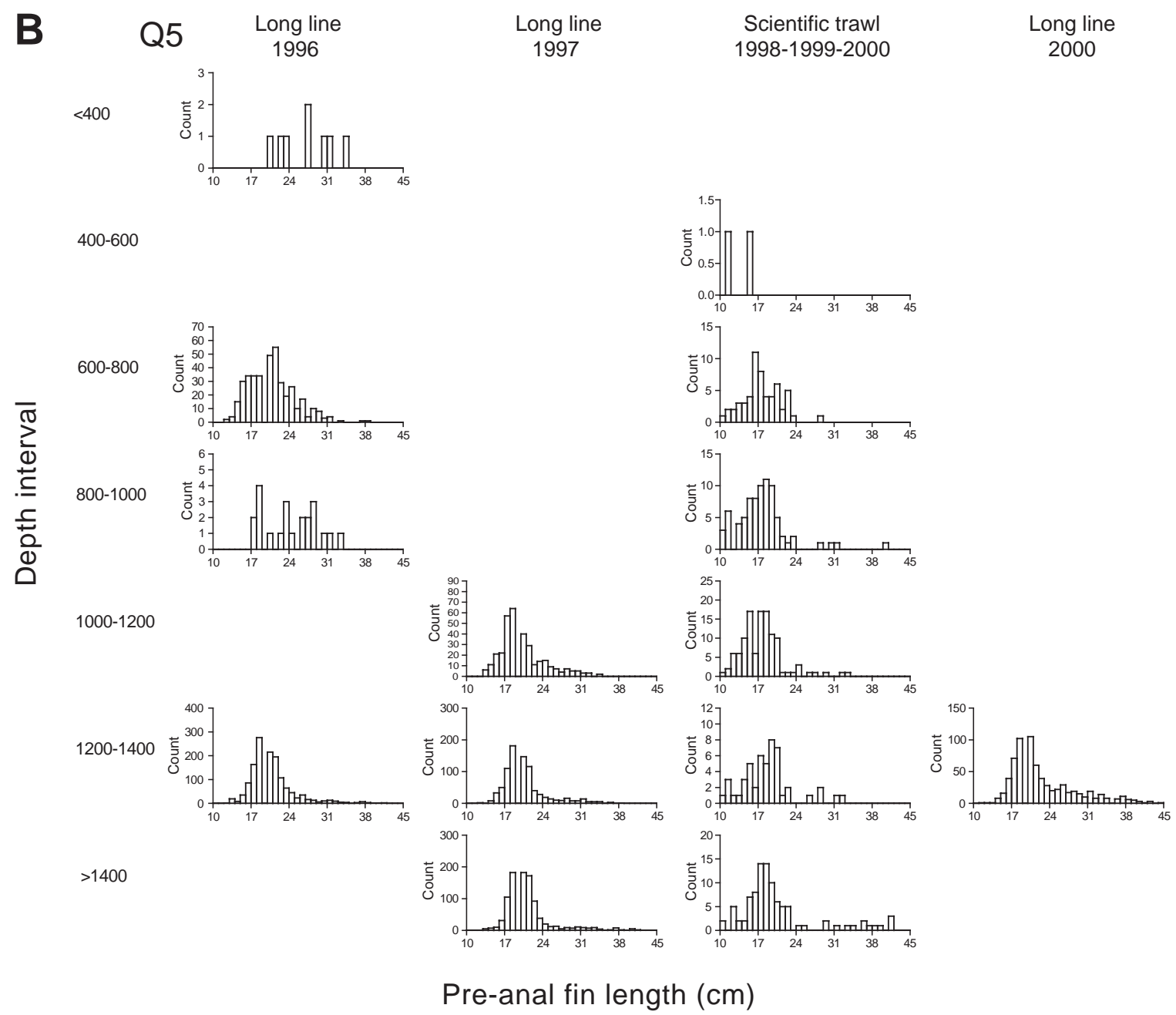

Fig. 5B. Pre-anal fin length $(P A F)$ distribution of roughhead grenadier. Example from subarea Q5 - data from scientific trawl surveys and longline surveys.

The PAF length where $50 \%$ of the females had reached maturation $\left(L_{50}\right)$ was estimated to be $29.5 \mathrm{~cm}$ in area Q5 and $29.7 \mathrm{~cm}$ in Q3, respectively. Males reached maturity at a smaller size and $L_{50}$ was estimated at $16.4 \mathrm{~cm}$ in area Q5. $L_{50}$ was estimated at $15.6 \mathrm{~cm}$ in Q3, but the latter estimation was based on only a few observations (Fig. 9).

\section{Potential fecundity}

Based on examination of 25 specimens in the length range $29-47 \mathrm{~cm}(P A F)$, sampled during the longline survey in 2000 , the potential fecundity was found to vary between 17000 to $56000 \mathrm{eggs}$, and fecundity increased with fish size (Fig. 10).

\section{Distribution}

\section{Discussion}

In the scientific trawl surveys the catch rates were generally highest in Q1 and very low in Q3 (Fig. 2) (Jørgensen, MS 2001). In the longline survey no clear patterns could be seen although catch rates seemed lower in subarea Q5, where most of the commercial fishery occurs (Fig. 3). The observed pattern indicates between areas differences in distribution mainly caused by natural variation. The commercial fishery seems, however, to affect the abundance in areas exposed to intensive fishing (see below). Between-area variation in catch rate has previously been reported from several other areas (Eliassen, MS 1983; 

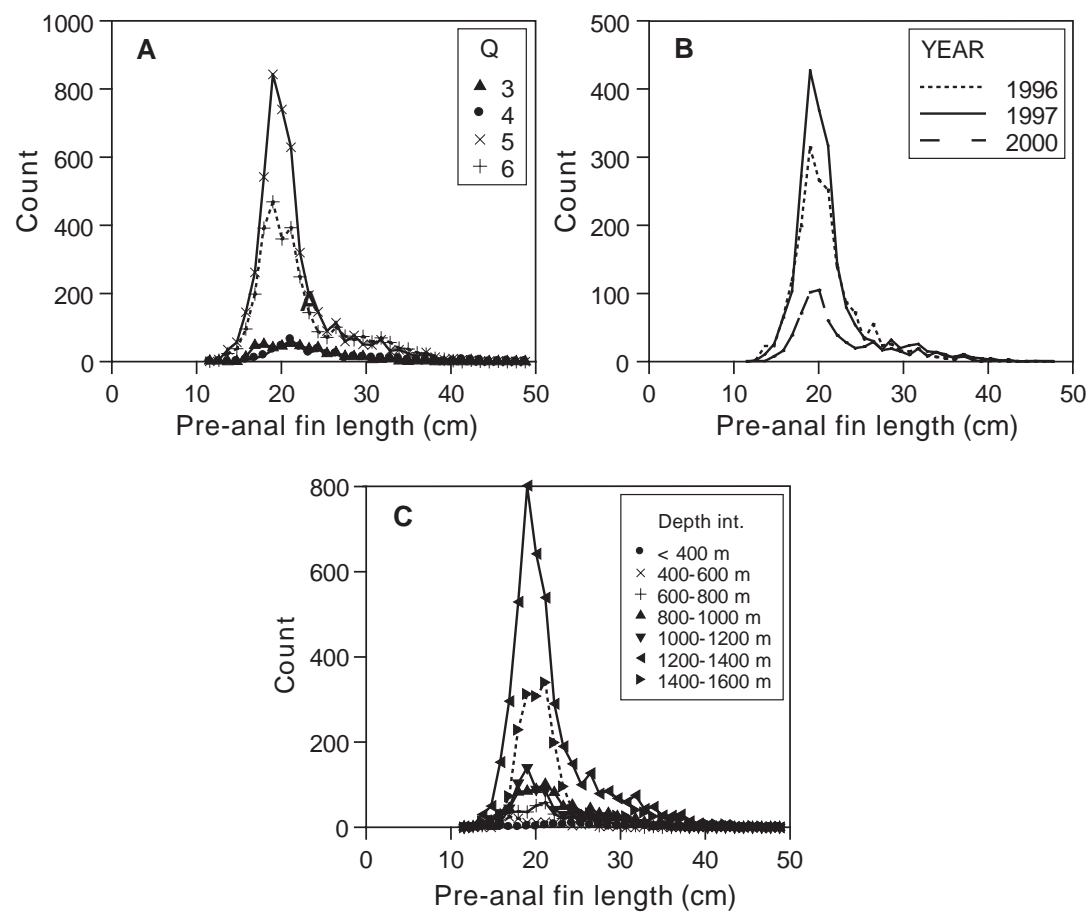

Fig. 6. Length distribution $(P A F)$ of roughhead grenadier from the pooled longline surveys. (A) Different areas (Q), (B) Data from area Q5 by years, and (C) Length distribution by depth strata.

TABLE 3. Probabilities for length distributions of roughhead grenadier, from different depth strata, being sampled from the same population using pooled data from longline surveys, based on two-sided Kolmogorov-Smirnov statistics.

\begin{tabular}{lccrrrr}
\hline \hline Depth $(\mathrm{m})$ & $200-400$ & $401-600$ & $601-800$ & $801-1000$ & $1001-1200$ & $1201-1400$ \\
\hline $401-600$ & 0.002 & & & & & \\
$601-800$ & 0.007 & $<0.001$ & & & & \\
$801-1000$ & 0.058 & $<0.001$ & $<0.001$ & & & \\
$1001-1200$ & 0.006 & $<0.001$ & 0.159 & $<0.001$ & & \\
$1201-1400$ & 0.004 & $<0.001$ & 0.005 & $<0.001$ & 0.346 & \\
$1401-1600$ & 0.004 & $<0.001$ & $<0.001$ & $<0.001$ & $<0.001$ & $<0.001$ \\
\hline
\end{tabular}

Jørgensen, 1996; Magnússon and Magnússon, 1995; Parsons, 1976).

In general catch rates were stable between years in the trawl surveys, except in the deepest strata in subarea Q5 where catch rates increased in 2000. This tendency was also seen in the longline survey where catch rates in the 1200-1 $400 \mathrm{~m}$ stratum were higher in 2000 compared to 1997 , but at the same level as in 1996. The result indicates a change in abundance, which might be caused by changes in the population distribution pattern. The longline data showed an increased proportion of larger fish in the $1200-$ $1400 \mathrm{~m}$ stratum from 1997 to 2000 , and hence the increased catch rates are not likely to be caused by an increase in recruitment, but rather in a redistribution of the fish.

In general catch rates were stable with regards to depth within most subareas for both scientific trawl and longline. The exceptions were found in area Q1 for trawl and Q5 for longline, which might be influenced by the commercial fishery in these areas. In the scientific trawl surveys catch rates seemed to peak 
Sci. trawl

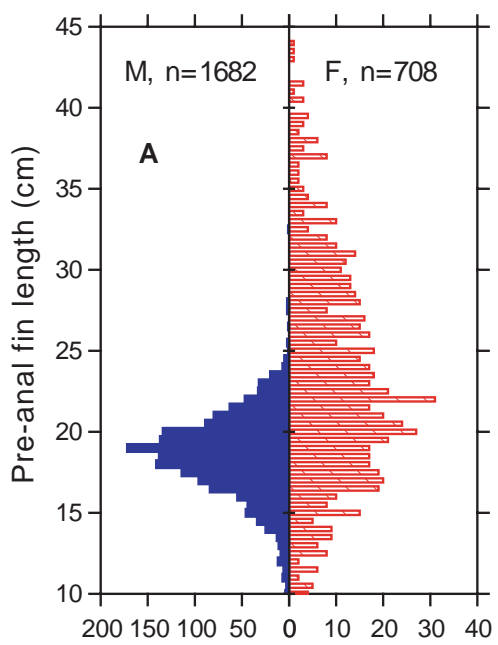

Long line (2000)

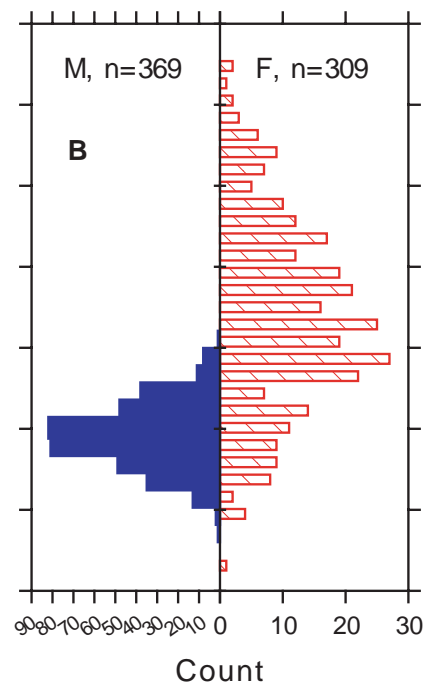

Total

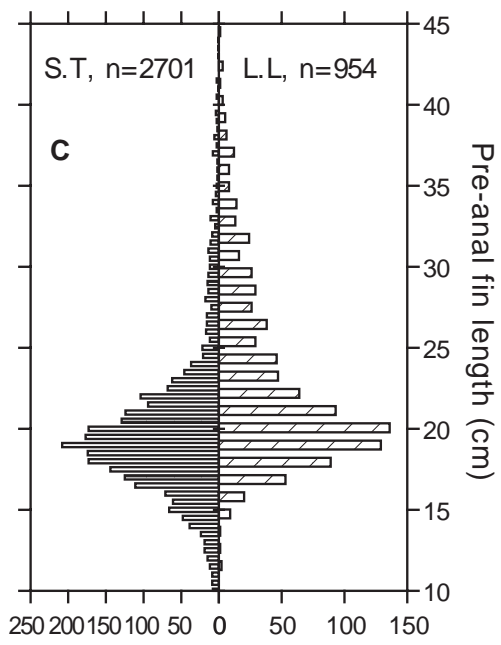

Fig. 7. Length distribution of roughhead grenadier $(P A F)$, divided by sex and gear. (A) Data from scientific trawl surveys combined, (B) data from longline survey during 2000 and (C) Total length distribution from the scientific trawl surveys and the longline survey during 2000.

TABLE 4. Probabilities for males and females occurring with equal frequency in samples within different depth strata based on Pearson Chi-square (Sci. T = Scientific trawl surveys; LL= longline surveys.)

\begin{tabular}{lcccccc}
\hline \hline Depth $(\mathrm{m})$ & $401-600$ & $601-800$ & $801-1000$ & $1001-1200$ & $1201-1400$ & $1401-1600$ \\
\hline Sci. T & $<0.001$ & $<0.001$ & $<0.001$ & $<0.001$ & $<0.001$ & $<0.001$ \\
LL & 0.668 & 0.237 & $<0.001$ & $<0.001$ & $<0.001$ & \\
\hline
\end{tabular}
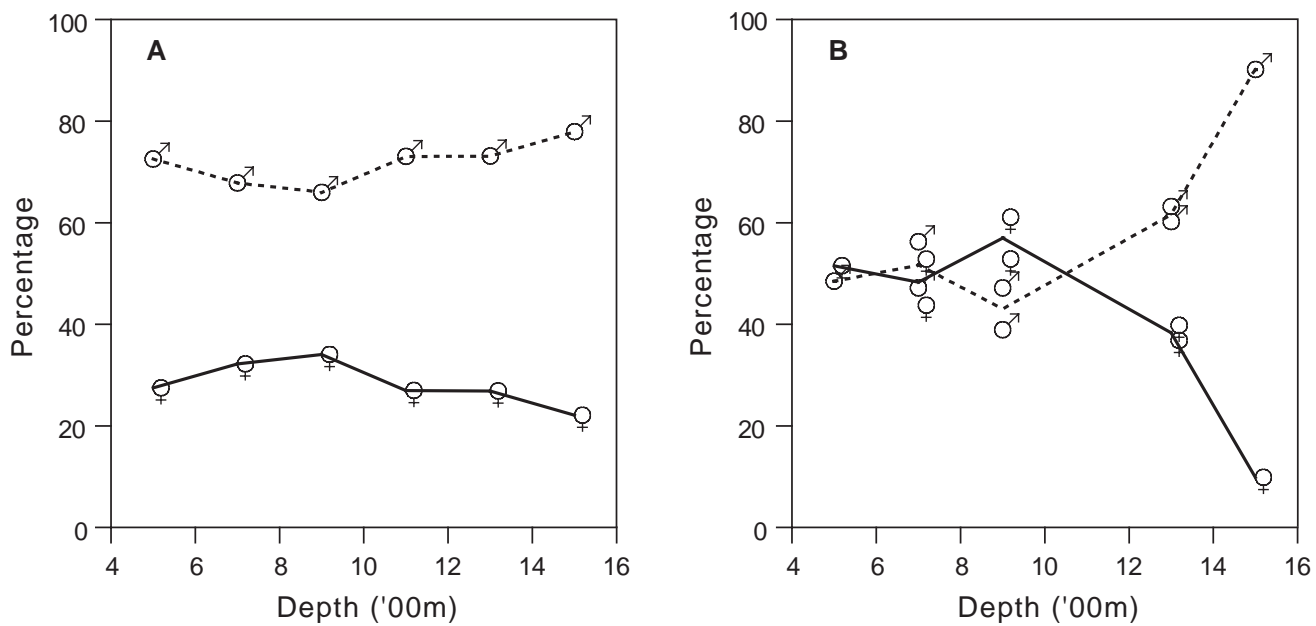

Fig. 8. Occurrence of males and females in catches by depth strata. (A) Pooled data from scientific trawl surveys $(\mathrm{N}=2390)$ and $(\mathbf{B})$ data from longline surveys $(\mathrm{N}=3374)$. 

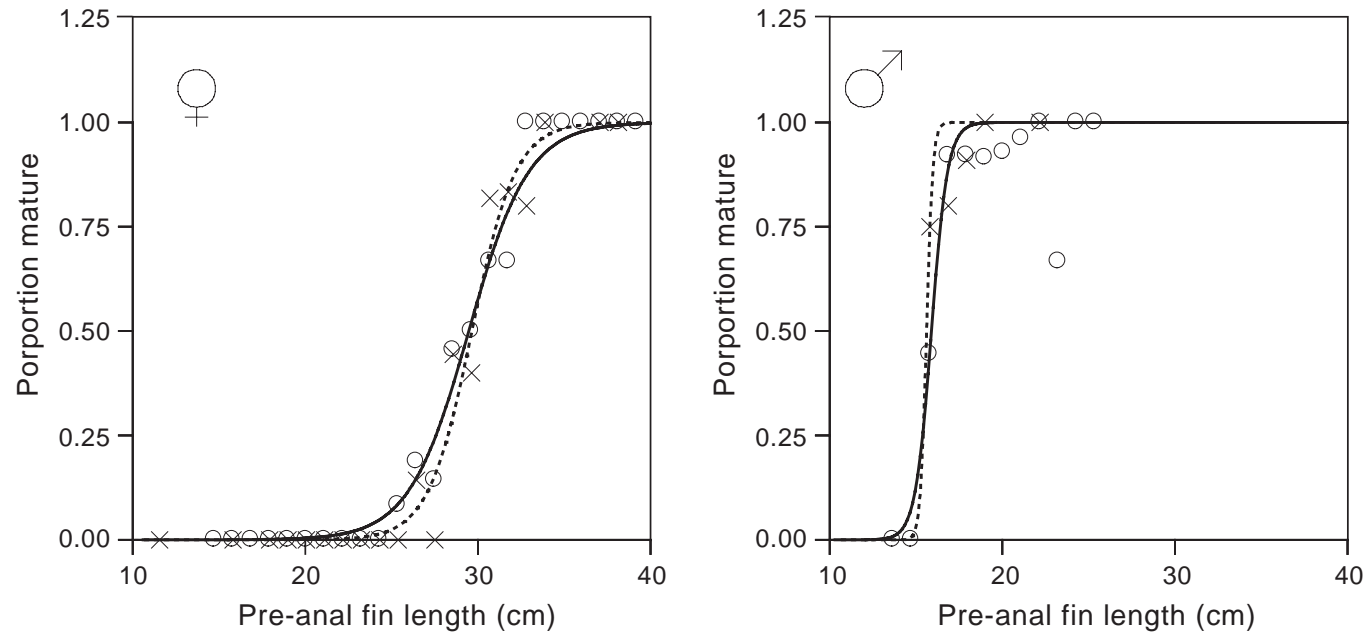

Fig. 9. Proportion mature/maturing roughhead grenadier and fitted logistic growth curves.

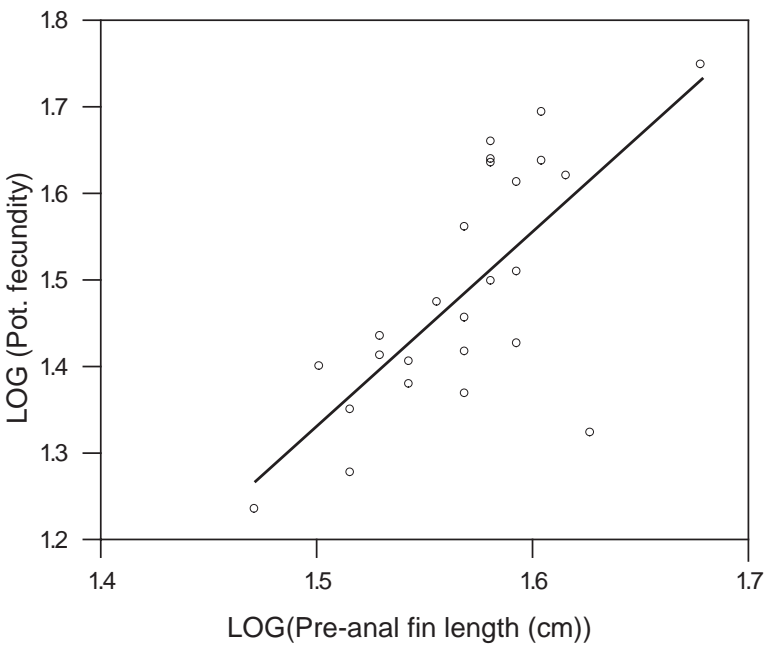

Fig. 10. Logarithmic relationship between potential fecundity and length $(P A F)$ of roughhead grenadier. Log Potential fecundity $(\mathrm{PF})=-2.042307+0.9966 \times$ Log Pre-anal fin length $(\mathrm{cm})(P A F), n=25, r^{2}=$ 0.514 .

between 800 and $1200 \mathrm{~m}$ (Jørgensen, MS 2001), which is also the depth with the highest catch rates at West Greenland (Jørgensen, 1996).

In East Greenland waters catch rates peaked at greater depths compared to what was observed in Norwegian (Eliassen, MS 1983) and Canadian waters (Parsons, 1976). This is believed to be due to higher temperatures in deeper water off East Greenland due to the Irminger current. All data were sampled during summer and the material do not indicate if the observed distribution pattern exists throughout the year or to what degree such changes may have affected the results.

\section{Length}

A modal peak around $20 \mathrm{~cm}(P A F)$ dominated the length distribution in catches for all gears (Fig. 4, 5). The very few small specimens, $<10 \mathrm{~cm}$, observed in the trawl surveys, despite the $30 \mathrm{~mm}$ mesh liner in the cod end, could indicate that small roughhead grenadier are found outside the range of the survey area and/or the depths covered (400-1 $500 \mathrm{~m})$.

Data from the scientific trawl and longline surveys showed a significant difference in the between gear length distribution and in the length distributions within the individual depth strata between different subareas. In general there was an increasing proportion of larger fish when moving from south to north. This could be due to natural distribution or by the longline fishery in the southern subareas, mainly Q5, that tend to catch relatively larger fish, or a combination of both.

Maximum length usually increased with depth. Although there was significant statistical difference in length distribution between depths strata, observed in both gears, generally this was caused by a high proportion of large fish $(>24 \mathrm{~cm})$ in the $800-1000 \mathrm{~m}$ depth stratum compared to other strata. This separation of length groups might be caused by intraspecific competition for food between length groups or preferences for a certain environment (temperature) (Eliassen, MS 1983) but might also be caused by mi- 
gration, possibly in relation to spawning. Different patterns where mean-length has increased (Cardenas, et al., MS 1996; Eliassen, MS 1983) or decreased (Parsons, 1976) with depth have been described for roughhead grenadier in different areas. This study shows that the length distribution in relation to depth is not that straightforward and may be related to other factors such as a change in sex ratio with depth (see below).

Due to selectivity a marked difference in length distribution was observed between gears. Longlines did not catch fish smaller than $15 \mathrm{~cm}$. Jørgensen (1995) also noted the lack of small fish in the longline catches at West Greenland. Generally longlines often catch larger specimens than trawls. This is particularly pronounced for species like Greenland halibut (Huse et al., 1999) and might be related to swimming speed. For fish larger than $20 \mathrm{~cm}$, however, this tendency is not that clear for roughhead grenadier neither in this study (Fig. 7) nor in the study at West Greenland (Jørgensen, 1995). The length distributions in the commercial and the scientific trawl catches were somewhat similar, especially in 2000 , with modes around $17-21 \mathrm{~cm}$, despite the difference in mesh size (30 $\mathrm{mm}$ and $140 \mathrm{~mm}$ in the scientific and commercial codends, respectively) (Fig. 5). Except for smaller fish $(<19 \mathrm{~cm} P A F)$ being increasingly prevented from biting over the hooks, length composition does not indicate large between-gear differences in size selection. This might be because roughhead grenadier is a slow swimming species in combination with a marked dominance by fish from a narrow length interval.

\section{Biological parameters}

A significant difference in length distribution between sexes was observed in both gears, where females were larger than males (Fig. 7). The growth rate is reported to be almost similar for the two sexes (Savvatimsky, 1994; Jørgensen, 1996; Murua, MS 2000). If this is true for roughhead grenadier off East Greenland, the skewed sex ratio in the larger sizeclasses could be caused by higher mortality rate amongst males. Catches were, however, dominated by small males, which could have simple biological reasons or, indicate that either both sexes not equally available to the gears or sampling is not representative (see below). Savvatimsky (MS 1985) suggest that the reason for females being less frequent in longline catches is because they reduce food intake during a period of time when they spawn. However, the dominance of males is also seen in the trawl catches so this can only be part of the explanation.
Sex composition varied markedly between depth strata (Fig. 8). Females were dominant between 800 and $1000 \mathrm{~m}$ in longline catches and males at greater depths. The male dominance was found in all depth strata in the scientific trawl surveys although it was less in the 800-1 $000 \mathrm{~m}$ depth strata. Such marked differences between depths might indicate a strong degree of intraspecific competition where the larger females dominate the most favourable depth, while smaller fish are displaced to less favourable areas (Wootton, 1990). Migrations, for instance in relation to spawning, might also induce similar patterns. Based on the indications from length frequencies and stage of maturity, however, the higher female proportion within some strata might partly be due to an aggregation of large immature females. This betweendepth strata variation in sex composition may also have resulted in a biased overall sex ratio.

The $L_{50}$ for males was about $16 \mathrm{~cm}$ (Fig. 9). Very few males $<16 \mathrm{~cm}$ were taken on the longlines, hence most males caught using that method were sexually mature $(>90 \%)$. The $L_{50}$ for females was estimated at $29.5 \mathrm{~cm}$. A conversion factor $(P A F$ length $=-5.736$ $+0.516 \times$ Total length, $n=191, r^{2}=0.976$; Møre Research, unpublished data) was used to make previous $L_{50}$ values comparable with our findings. Estimated $L_{50}$ for females in this study was slightly higher than previous estimates reported both by Eliassen and Falk-Petersen (1985) (65 cm total length which corresponds to $27.8 \mathrm{~cm}$ PAF), and Murua and Motos (2000) $(66.7 \mathrm{~cm}$ total length corresponding to 28.7 $\mathrm{cm} P A F)$. The observed differences are however small and might be within the variability range of the estimates. According to these authors the corresponding age at $50 \%$ maturity was 13.5 years (Murua and Motos, 2000) and 15 years (Eliassen and FalkPetersen, 1985).

The fecundity increased with fish size (Fig. 10). The number of eggs in this study varied between 17 000 and 56000 per individual. This is in agreement with Murua and Motos (2000) who reported that the number of eggs to be between approximately 14000 and 80000 per individual.

\section{Concluding remarks and significance}

The observation of differences between area and depth strata in catch rates seems to be caused by the general distribution pattern and changes in this. Separation of sex and length groups by depth strata is partly responsible for the observed variation in catch rates. This separation may indicate a strong degree of 
intra-specific competition between length groups. Changes in length distribution with depth is, however, not straightforward and is linked to a between-depthstrata change in sex ratio. Small males dominated the catches and females grew larger than males. The study does not give any straight forward explanation to this phenomenon but between-depth strata variation in sex composition would to some degree have biased the overall sex ratio. Estimated value of $L_{50}$ for females $(29.5 \mathrm{~cm})$ was in accordance with previous findings in other areas. Logarithmic relationship between potential fecundity and length $(P A F)$ of roughhead grenadier was estimated to be: Log (Potential fecundity $)=-2.0423+0.9966 \times \log (P A F), n=25, r^{2}$ $=0.514$.

With a steadily increasing commercial fishing interest for new areas and species, it is important to utilize all available information to describe new areas and systems in an early phase of exploitation. This is especially important for species which may be caught directly or indirectly in new commercial fisheries. Understanding distribution and migration pattern are essential to fully understand variation in catch composition and ratios.

\section{Acknowledgement}

The present study is based on results from several projects, which have been funded by the Greenland Institute of Natural Resources, the Norwegian Research Council and the Greenland Home Rule. Thanks to the crews onboard the different commercial and scientific vessels involved in sampling, and to technical personnel involved in data collection and analyses. Thanks to the editor and anonymous reviewer for their constructive comments to the manuscript.

\section{References}

ANON. 2002. NAFO Scientific Council Report, 2001. NAFO Sci. Coun. Rep., 339 p.

ATKINSON, D. B., AND D. POWER. MS 1987. Distribution of roughhead and roundnose grenadier in the Northwest Atlantic. NAFO SCR. Doc., No. 94, Serial No. N1398, $28 \mathrm{p}$

CARDENAS, E., J. M. CASAS, R. ALPOIM, and H. MURUA. MS 1996. Preliminary results of the eropean long-line survey in the NAFO regulatory area. NAFO SCR Doc., No. 34, Serial No. N2709, 6 p.

CLEVLAND, W. S. 1979. Robust local weighted regression and smoothing scatterplots. J. American Stat. Ass., 74: 829-836.
ELIASSEN, J. -E. MS 1983. Depth distribution of roughhead grenadier (Macrourus berglax Lacepede) in relation to hydrographical conditions along the continental slope of northern Norway. ICES C.M. Doc., No. G:42, 17 p.

ELIASSEN, J. -E. and I. B. FALK-PETERSEN. 1985. Reproductive biology of the roughhead grenadier from the continental slope of northern Norway. Sarsia, 70: 59-67.

FOTLAND, A., A. BORGE, H. GJØSÆTER, and H. MJANGER 1997. Håndbok for prøvetaking av fisk og krepsdyr. Havforskningsinstituttet i Bergen, 146 p.

GEISTDOEFFER, P. 1979. New data on the reproduction of macrourids (Teleostei, Gadiformes). Sarsia, 64: 109112.

GUNDERSEN, A.C., O. KJESBU, A. STENE, and K. H. NEDREAAS. 1999. Fecundity of the northeast Arctic Greenland halibut (Reinhardtius hippoglossoides). J. Northw. Atl. Fish. Sci., 25: 29-36.

GUNDERSON, A. C., J. E. RØNNEBERG, and J. BOJE. 2001. Fecundity of Greenland halibut (Reinhardtius hippoglossoides) in East Greenland waters. Fish. Res., 51: 229-236.

HUSE, I., A. C. GUNDERSEN, and K. H. NEDREAAS. 1999. Relative selectivity of Greenland halibut (Reinhardtius hippoglossoides, Walbaum) by trawl, longlines and gillnets. Fish. Res., 44: 75-93.

JØRGENSEN, O. A. 1995. A comparison of deep water trawl and long-line research fishing in the Davis Strait. In: Deep-Water Fisheries of the North Atlantic Oceanic Slope. A.G. Hopper (ed.). Kluwer Academic Publishers, p. $235-250$.

JØRGENSEN, O. A 1996. Distribution and biology of grenadiers (Macrouridae) in West Greenland Waters. J. Northw. Atl. Fish. Sci, 18: 7-29.

JØRGENSEN, O. A. MS 1998. Survey for Greenland halibut in NAFO Divisions 1C-1D. NAFO SCR Doc. No. 25, Serial No. N3010, 26 p.

JØRGENSEN, O. A. MS 2001. Survey for Greenland halibut in ICES Division 14B, June-July 2000. Working Paper 2 for ICES Northwestern Working Group, 33 p.

KATSAROU, E., and G. NÆVDAL. 2001. Population genetic studies of roughhead grenadier, Macrourus berglax L., in the North Atlantic Ocean. Fish. Res., 51: 207-215.

MAGNÚSSON, J. V., and J. MAGNÚSSON. 1995. The distribution, relative abundance, and biology of the deepsea fishes of the Iclandic slope and Reykjanes ridge. In: Deep-Water Fisheries of the North Atlantic Oceanic Slope. A.G. Hopper (ed.). Kluwer Academic Publishers, p. 161-199.

MURUA, H., and L. MOTOS. 2000. Reproductive biology of roughhead grenadier, Macrourus berglax Lacepède, 1801) (Pisces, Macrouridae), in Northwest Atlantic waters. Sarsia, 85: 393-402.

MURUA, H. MS 2000. A review on roughhead grenadier (Macrourus berglax) biology and population structure on Flemish Cap (NAFO Division 3M), 1991-1999. NAFO SCR Doc., No. 30, Serial No. N4259, 19 p.

OLSEN, H. E. 1995. Norwegian experience of deep-water fishing with longlines. In: Deep-Water Fisheries of the North Atlantic Oceanic Slope. A.G. Hopper (ed.). Kluwer 
Academic Publishers, p. 367-373.

PARSONS, L. S. 1976. Distribution and relative abundance of roundnose, roughhead and common grenadiers in the Northwest Atlantic. ICNAF Sel. Pap., 1: 78-88.

SAVVATIMSKY, P. I. 1969. The grenadier of the North Atlantic. Trudy PINRO, p. 3-72. (Translated from Russian - Fish. Res. Board Can., Transl. Ser. No. 2879.)

SAVVATIMSKY, P. I. 1984. Biological aspects of roughhead grenadier (Macrourus berglax) from longline catches in the eastern Grand Bank area, 1982. NAFO Sci. Coun. Studies, 7: 45-51.

1985. Ecological characteristics of the roughhead grenadier, (Macrourus berglax), near the Lofoten Islands. Voprosy Ichthiologii. Journal of Ichthyology,
25(5): 23-29.

MS 1985. Features of spawning concentrations of roughhead grenadier, Macrourus berglax L., at the Norwegian coast. ICES C. M. Doc., No. G:6, 34 p.

1994. Age structure of roughhead grenadier (Macrourus berglax) in the Northwest Atlantic, 1985. NAFO Sci. Coun. Studies, 20: 53-64.

SWAN, S. C., and J. D. M. GORDON. 2001. A review of age estimation in macrourid fishes with new data on age validation of juveniles. Fish. Res., 51: 177-195.

WOOTTON, R. J. 1990. Ecology of teleost fishes. Chapman and Hall, London, 404 p.

ZAR, J. H. 1984. Biostatistical analysis. $2^{\text {nd }}$ ed. Prentice Hall, Englewood Cliffs, New Jersey, 718 p. 